Portland State University

PDXScholar

1972

\title{
Guidelines for Agency Based Day Care Programs for Children Ages 0-3 years
}

Elizabeth H. Minifie

Portland State University

Follow this and additional works at: https://pdxscholar.library.pdx.edu/open_access_etds

Part of the Social Work Commons

Let us know how access to this document benefits you.

\section{Recommended Citation}

Minifie, Elizabeth H., "Guidelines for Agency Based Day Care Programs for Children Ages 0-3 years" (1972). Dissertations and Theses. Paper 1576.

https://doi.org/10.15760/etd.1575

This Thesis is brought to you for free and open access. It has been accepted for inclusion in Dissertations and Theses by an authorized administrator of PDXScholar. Please contact us if we can make this document more accessible: pdxscholar@pdx.edu. 
GUIDELINES FOR AGENCY BASED DAY CARE PROGRAMS FOR CHILDREN AGES $0-3$ YEARS

by

ELIZABETH H. MINIFIE

A practicum submitted in partial fulfillment of the requirements for the degree of

MASTER OF

SOCIAL WORK

Portland State University

1972 
CHAPTER 1

CHAPTER 2

CHAPTER 3

CHAPTER 4

CHAPTER 5

APPENDIX

Part A.

Part B.

Part C.

Part'D.

CHAPTER 6

FOOTNOTES

SELECTED BIBLIOGRAPHY
Nature of Problem:

Evaluating the Need for Infant

and Toddler Group Day Care

1

Statement of Purpose and Goals

Development of Guidelines for

Agency Based Group Day Care

Programs for Children Ages 0 -

3 Years

12

Methods of Preparing Practicum

15

Proposed Solution: Guidelines

for Agency Based Infant and

Toddler Group Day Care

Developmental needs of young

children

17

The group day care environment:

a balance of experiences 20

1. Size of program - Table $1 \quad 24$

2. Use of space 25

3. Play 27

4. Níaterials 29

5. People - staff 32

director - Table $2 \quad 36$

6. Parent involvement - Table 3. 37

7. Grouping of children - Table 438

8. Starting age - Table $5 \quad 40$

9. Facilitating Separation and Adjustment $\quad 42$

10. Health Care and Discipline 43.

Justification as a System $\quad 46$

Single versus Multiple Mothering 46

Peer group attachment : 48

Maternal and Child Health Intervention and Prevention $\quad 50$

Keeping versus Developing : 51

Remaining Problems

Public attitude and lack of clear cut goals

Sample Questionnaire $\quad 56$

Tables

63

68 
Your childręn are not your children.

They are the sons and daughters of Life's longing for itself.

They come through you but not from you,

And though they are with you yet they belong not to you.

You may give them your love but not your thoughts,

For they have their own thoughts.

You may house their bodies but not their souls,

For their souls dwell in the house of tomorrow, which you cannot visit, not even in your dreams.

You may strive to be like them, but seek not to make them like you.

- Kahlil Gibran, The Prophet 


\section{CHAPTER ONE}

NATURE OF PROBLEM: EVALUATING THE NEED FOR AGENCY BASED INFANT AND TODDLER GROUP DAY CARE.

The purpose of this practicum is to demonstrate the need and appropriateness of agency based group day care programs for children ages 0 - 3 years, to indicate some guidelines based on a collation of recent, but partial and not fully developed studies consistent with the aim of maximizing the socialized development of each child, with certain desired characteristics in mind as end products. Day care needs have been studied from several approaches: on a city, state and national level describing the need in terms of "slots" to fill, and from a neighborhood based approach where needs are being met by neighbors in "natural" arrangements. These approaches, however, do not fully take into consideration the role that public attitude has taken in making day care what it is today - a social problem.

A social problem by definition is a condition which is de- fined by a majority or significant minority as a deviation from some social norm. It is the product of social attitudes, values and institutions and its soltuion can only be found by a change in the existing social structure. ${ }^{1}$ Society tends either to deny the problem or to attribute its cause to external factors or to seek quick results without analyzing adequately the source of the problem. In this context, society makes day care a social problem by defining it as a social service for families in need. Day care centers are mushrooming across the country but with - a minimum of of supervision and controls to maintain high quality 
and standards. Parents pay approximately $\$ 100$ a month per child for private day care or they must prove inability to pay in order to be eligible for the service under social agency auspices. ${ }^{2}$ Federal and state funding reflects this attitude by providing day. care dollars for "past, present or potential welfare clients." 3 In reality, the need for day care is on an institutional level with families from every socio-economic group desiring some form of supplementary care for their children. The growth of this need can be seen in the changing patterms of society, and how they have affected changes in the family itself. In the past, - the family as an institution was patriarchal, authoritative, lived in a rural setting (its members were nearby geographicallÿ.) and was in effect an economic and social unit. The extended family, as it was known to be, was responsible for the socialization of its members; emotional, social, educational and occupational role differentiation and expectations were learned and internalized by the child from his family.

Through the process of urbanization and industrialization, the extended family has been replaced by the nuclear family which is characterized by social, geographical and occupational mobility which has disrupted family life, leaving families loosely integrated with society and affecting its mental health and stability. There is a real fragmentation of family life and less communication due to the many diversions which isolate and divide family members. The majority of activities take place outside the home. The importance of teaching child-rearing techniques has diminished leaving many present day parents without even basic child care 
knowledge. As a result, much child-rearing depends on a parent's "instincts" or on their mother, neighbor or friend's suggestion and not on the specific developmental needs of the child, The present generation of young middle-class mothers was raised by . upwardly mobile parents. Activities increasingly took place outside the home and babysitting became a means of earning extra spending money and not of learning and practicing specific child-rearing techniques. There exists today a large group of women who at the birth of their first child have never warmed a bottle nor changed a diaper. Some depend on a few weeks' course at the YWCA to learn how to care for an infant and others read Dr. Spock. All this demonstrates the amount of importance society places on child-rearing.

In reality, our culture is not child-oriented. Traditionally; in the United States, the Government takes little official interest in the average child between his arrival, when a birth certificate is required, until he is six years old, when the compulsory school attendance law takes effect. The assumption has been that families took care of these early childhood jears. Yet the evidence is all around that for some children, the family system is not doing the necessary job of preparing them for life. For other children, the family is a viable emotional unit providing some strengths, but the fathers and mothers are so overwhelmed by adverse circumstances (sickness, ignorance, mental illness, inability to cope with competitive, sophisticated city life) that those families need help. in preparing their young children for school and later life. Other children have competent 
parents who can cope with life in adult terms but who, out of ignorance, irresponsibility, or selfishness, are not giving priority to their duties as parents; these children also need help. ${ }^{4}$

(Society can ignore the needs of these children but it cannot ignore them indefinitely or without cost. Sooner or later, a sizable number of them are going to show up as juvenile delinquents, as mentally retarded children, as emotionally disturbed patients in institutions, as adolescent drug addicts, or criminals in prisons. As we continue to view day care within a residual framework, the needs of these children continue to be ignored. For example, on December 9, 1971 President Nixon vetoed an anti-poverty bill which had as its major component the Comprehensive Child Development Act of 1971, one of the most far-reaching measures ever passed by Congress. The sponsors of this bill recognize the need for a new institution in society, the institution of organized supplementary child care for all children whose parents need it.)

Thus, the process of socialization (by which people acquire a culture) as a family function has been in part taken over by formal institutions such as day care, nursery schools, Head Start, camps, after school programs, boarding schools, Scout groups, Little League and community centers. The high degree of differentiation between these social institutions in modern society might lead one to question whether the traditional family is needed at all. Many new family life styles are evolving to try to meet the demands of a constantly changing society which the nuclear family 
has been unable to meet. As Elizabeth Herzog points out in her booklet entitled Children of Working Mothers the idea that a child must be cared for only by his own mother or by one constant is a cultural rather than a universal belief. One only need to look at the frequency of "assistant mothers" in primitive societies as well as nannies or governesses in occidental culture and the absence of evidence that children or the adults they become, are harmed by it. ${ }^{5}$ Some women, in fact, are better mothers if these mothering activities are part-time rather than furl-time.

The most important point to consider at this time is that the care must be adopted to the child's needs, for it is the quality of care and training the child receives that is more important than who does it.). The losis of family function so to speak, can be seen positively as the family learns to compensate by enhancing the quality and quantity of fewer functions and to share the care of children with other institutions. The trend, according to Howard Halpern in his article "Alienation from Parenthood in the Kibbutz and America", is toward greater parental freedom as parents put an intermediary between themselves and their children. 6

Phillip Fellin in his article entitled "A Reappraisal of Changes in American Family Patterns" raises the question of which family function is better performed by the family and which by an institution outside the family. He feels that there is a need for coordination of efforts among formal organizations and primary groups in order to give maximum benefit to the family and society. 
As an example, Mr. Fellin feels that the family is responsible for the most nonuniform, idiosyncratic tasks whereas the organization is responsible for certain uniform and repetitive tasks."

As the growth in parent-surrogate institutions offering children guidance, instruction, impulse control, socialization, warmth and a sense of belonging becomes more prevalent, we must ask ourselves what culture, what values do we want transmitted to our children and how can families and social systems coordinate this process of socialization. How can we best prepare our children for the future and how can we ensure maximum performance of highest quality.

First of all, day care must be seen within an institutional framework in order to guarantee good quality of care. Since it shares in the socialization process of children, day care must not be considered as a babysitting service or solely as a service for the poor, but as an effective, positive, educational experience for children of parents who do not "need it" as well as for children of parents who do. ${ }^{8}$ In this way, all parents needing supplementary care will feel a personal investment in day care.) Too often, maternal employment is equated with poverty, deprivation, and emotional problems. 9 Working parents have long felt this stigmatism and carried the burden of guilt over putting their children in day care, alleviated only during wartimes when women had to join the workforce. Industry has attracted more women into the labor force but only recently through the efforts of the women's liberation movement have women been able to feel comfor.. table about needing fulfillment outside the home. 
Florence Ruderman describes working mothers and their child care arrangements in her book entitled Child Care and Working Mothers. Thirty-three per cent of all mothers of children under twelve years of age work and many others would like to and plan to in the future. ${ }^{10}$ These women come from all strata and in great majority from normal intact families. Working mothers are less subject to many psychological difficulties created by the pressure to single-handedly raise their children. (By sharing the socialization process with day care, parents will not be so emotionally invested in the success or failure of their children, thus relieving pressure and allowing children the freedom to grow and develop at their own rate?

Preparing our children for the future means preparing them for change. One must not learn to adjust to change but rather he must learn ways in which to make use of it. For the growth and development of our children, this does not indicate the absorption of knowledge, but a way of discovering knowledge in a constant process of re-education in the light of what is currently new. ${ }^{11} \mathrm{We}$ must provide our children with the techniques of managing knowledge to do productive work and to fill leisure time. The pursuit of pleasure will have to be accepted as a virtue. Pleasure will have to cease being equated with non-doing and idleness and come to be associated with self-management, with self-imposed and sèlf-chosen activity. 12

The isolation of the nuclear family has inadvertently created a vacuum of personality traits which do not lend themselves to building a better society but rather lead to further isolation. 
As Ruderman states, "Americans remain prisoners of their illusion that each family can stand alone - independent and self-sufficient."13 Neatness, mistrust, competition, closedness and possessiveness only get in the way of building better human relationships. Through day care, the socialization process can work to change these negative characteristics by providing an atmosphere of openness, generosity, trust, sharing and much physical touching and cooperation. 14 This will not work to undermine the family but to enhance it by sharing in the socialization process. The majority of dày care arrangements are informal, unorganized child care arrangements, that is: $73 \%$ are in home arrangements where care is given by father, sibling or relative, $17 \%$ of care is given by non-relatives outside of the home called family day. care mothers, $7 \%$ of children are alone and $3 \%$ are cared for in group care such as day care centers or nursery school. 15 These statistics reflect society's system of priorities and an attitude of serious neglect toward our children. In home arrangements often creates domestic strain and conflict as the mother is reluctant to criticize or demand too much. ${ }^{16}$ Family day care arrangements have their problems also. They are often not dependable and do not provide a consistent and stable environment for the child as they are constantly changed due to transportation, personal problems, and to dissatisfaction with care given and/or care received. The quality of care is often questionable because of the lack of supervision in non-lieensedhomes and in many: cases lack of knowledge of the developmental needs of children. 
In a study of mothers using family day care conducted in New York on a Children's Bureau grant, Willner, Vernon, Hunter, and Schrieber found that they had "reason to fear that while the day care of her very young children is the best the mother knows how to provide or can afford, it frequently is care which can actually damage the child. . Too often children are being left with a neighbor too old, or too young, or too tired, or too limited in intelligence to give the child proper care". 17 Family day care mothers also.suffer from society's attitude that they should. be "substitute" mothers providing a "home" atmosphere for a child who is considered not to have a functioning mother, home, and family. The women who take on the job are not thought of as professionals, but as people who are not qualified to do anything else. In other words, they are at the bottom of the employment ladder and the fees also reflect this. Volunteers of America Family Day Care Mothers in Portland, Oregon, receive $\$ 3.00$ a day per child which includes the noon meal.

In actuality, children of working mothers do not need a substitute home, family, and mother but rather supplementary care given by skilled, responsible warm, affectionate and attentive people. ${ }^{18}$ These qualities can be found in home and family day care homes as well as in agency based group day care programs. Nursery schools, head start and group day care are usually available for the enhancement of the socialization process for the child between the ages $2 \frac{1}{2}$ to 5 years. However, the care of infants has been left to. whatever informal arrangements a family can make, with the quality of care totally dependent on the care 
giver. Some parents prefer this type of child care arrangement. Arthur Emlen in his paper entitled "Realistic Planning for the Day Care Consumer," describes the preference patterns of a sample of working mothers who were white and largely middle-class and Iiving in Portland, Oregon. He found that $72 \%$ of the Portland women using family day care reported preferences for family day care over group care in a day care center. 19

However, dissatisfaction does exist as described earlier. Fiorence Ruderman found that "the greater the dissatisfaction the mother feels with her present arrangement, the more likely she is to be attracted to the idea of a child care center, (and) dissatisfaction was higher when infants were involved." 20 Among mothers with children under 3 , the highest rate gave a positive response to group care for children under 3 years. 21 She also found that among working mothers in all communities, racial and socio-economic, $47 \%$ feel they probably would use a high quality child care center under community and social agency auspices because it promises good quality, constructive care for the child, security and convenience for the mother, dependability, good care, feeling of confidence and solution to many existing problems. 22 A good child care center was seen as having certain values in itself rather than as a last resort. She concluded that the "need for higher standards, better supervision and quality control, and more highly trained personnel can be achieved in child care centers: for infants than can be brought about in hundreds or thousands of scattered family day care homes."23

Much research indicates that the years between 1 and 3 
11

are the most important in terms of a child's intellectual and emotional development. I. B. Murphy states that Head Start is too late as studies suggest that by age 3 , children already show cognitive deficits and emotional deprivations. 24

B. M. Caldwell in her article entitled "The Rationale for Early Intervention" points out that between the ages 18 months and .3 years, differences in cognitive level and style begin to appear between children from relatively privileged and underprivileged backgrounds. 25 Sally Provence states that "services to enhance a child's development should be available to him as early in his fife as possible. $" 26$ 
STATEMENT OF PURPOSE AND GOALS

With this information and the day care situation as it is today emerges the need for the development of agency based group care programs for infants and toddlers to be proposed, explored, studied, tested and evaluated. For, assessment can only be made after a realistic appraisal of the experiences that the setting. provides. Agency based group care for infants and toddlers will help to draw public attention to the need for quality day care for all parents and children needing care and to change public attitude toward child-rearing of infants and toddlers from one of "hitor-miss" to a concentrated effort to allow each child to develop to his highest capacity both emotionally and intellectually. Such programs will enhance the parents' child-rearing, alleviate parent-child pressures and detect at an early and reversible stage, any problems that might develop.

Many of the group programs in existance today for the 0 to 3 years age child are on an experimental basis because of the fear of its effects on young children. Dr. John Bowlby is one of the sources of this fear because of his findings that children in Institutions were found to suffer from "institutionalism": they were less interested and displayed physical and emotional defects. 27 . But these effects were the result of the lack of stimulation and not from the fact that they were cared for in groups.

Much of the results of the research from these programs wil. be helpful in developing guidelines for future infant and toddle: 
group care programs. However, since some of this research was performed with disadvantaged groups needing so called compensatory types of cognitive stimulation, the programs were highly structurëd and programmed. It is my aim to steer away from the rigidity of these programs, not discounting them, in order to develop a more balanced approach to the multiple needs of young children. Another aim in developing these guidelines will be to avoid the nursery school model which so many day care centers use. In visiting a day care center in the Portland area, I was dismayed to see that the toddlers were expected to participate in group activities sitting in chairs at a table. Imposing such controls on young children indicates an ignorance of their developmental needs. It is therefore extremely important to stress that when developing guidelines for programs for very young children an understanding of their physical, emotional, psychological and intellectual developmental needs must come first. Quality day care enables growth through child-centered activities, rather.than achieving order through adult centered management. Infants need a different kind of care from preschoolers because their day care experiences must be differentiated for children at different ages of development. Very young children to begin with need continuity in care and more personalized and affectionate care. Ruderman believes that these needs may well "be more securely met in an organized, professional setting . . than in isolated, unsupervised, unprofessional private homes." 28 Because of the vulnerability of infants, day care should be developed as a professional service of voluntary, independent centers under diverse and perhaps multiple sponsorship 
in order to be able to innovate and insure high standards and to avoid the pitfalls of a mass custodial service and huge centralized program. 29

My purpose in this practicum is to develop guidelines for agency based infant group care programs so that an optimal environment may be provided for a group of infants and toddlers who vary in socio-economic status, race and sex. The state of Oregon and city of Portland is in the process of developing such guidelines and it. is my aim that this practicum will be of some value in their efforts. Also, Fruit and Flower Day Nursery in Portland expressed a desire to know more about the need for infant group care and it is my aim to provide them with some information on the subject. Perhaps they will take the initiative and launch an infant care program:

There are limitations to my efforts starting with the fact that I am no expert in the fields of child development and can only depend on my methods of accumulating information for this practicum for credibility; verification and justification.

I do not intend to discuss staffing, hours, and finsncial aspects of running a day care center nor the health and dietetic needs of young children as these issues can be better dealt with by the agency director, pediatric nurse and dietician. These guidelines will attempt to provide for a day care environment from which children will draw all the things they need to grow individually, healthily and happily. 
CHAPTER THREE

METHOD OF PREPARING PRACTICUM

Preparation for this practicum involved a review of the pertinent literature between 1960 and 1972 in the field of day care, early child development and Israeli Kibbutz life. The data was collected on cards.

Field observations were made at two day care centers in New York, New York in June 1971: the Riverside Infant Day Care Center, 490 Riverside Drive; and the Infant Care Unit of the Child Development Center, 201 W. 93rd St., and in Portland, Oregon at the Lincoln Street Baptist Church Infant Day Care Program, 3240 S.E. Iincoln, and at the Portland State University Child Care Center.

My field work placement during the 1971-1972 academic year has been at the Special Day Care Center in Portland, Oregon, a day treatment center for emotionally disturbed children ages 3 to 8 years. Much information has come from this experience as well as from a weekly volunteer job at Fruit and Flower Day Nursery at Trinity Episcopal Church where the twenty children are grouped together, ages $2 \frac{1}{2}$ to 6 years. I must also mention my observations, although they may not be that objective, of my daughter, Rachel, who will be 3 years old on June 16, 1972. She has given me much insight into the needs of a young child during each growth period as well as first hand information and experience in the Volunteers of America: family day care program with which we have been involved during the 1971-1972 academic year. :nformation was also gathered from a questionnaire which was 
prepared to survey the ideas and feelings of working mothers using Fruit and Flower Day Nursery. It was sent to eighty-eight parents along with the Fruit and Flower Day Nursery parents' February Newsletter. Few responded and so personal requests were. made to parents as they picked up their children from the Day Nursery. Thirty-four parents. responded. This is not an official random sample to be evaluated but simply an attempt to have some parental involvement in the preparation of this practicum. A sample of the questionnaire along with five tables based on it are submitted under Appendix...

All this information has been organized into a format which includes: a. statement of the problem, a proposed solution and a justification of that solution as the main areas of discussion: Federal Inter-Agency Requirements and city building codes have not been Included. 


\section{CHAPTER FOUR}

\section{PROPOSED SOLUTION: GUIDELINES}

Knowledge of the nature of growth in the child provides us with a dependable guide to the developmental and growth needs of infants and toddlers. There are predictable sequences in his developments and each step depends on the successful achievement of the previous step. 30 Just what gives the child the impetus to go ahead and grow involves an inner life force. Dorothea Gilbert describes this as "a feeling that the world is $0 . \mathrm{k}$, a sense of trust - of sureness and of safety. But it goes on through all his life. . When he is an infant and cries, you hold him. His crying tells you that he wants some loving; his relaxation and happiness and peace tell you that you are right when you give it to him". 31

\section{Developmental Needs of Young Children}

Curiosity and desire for knowledge are also part of this life force, the neuropsychological basis of which is represented by the group of reflexes connected with orientation, investigation and Imitation. The child also strives for social contacts, for attachments, the neuropsychological basis of which is represented by smiling, contact reflexes and crying. 32

The behavior of an infant has an all-or-none quality to it. He reacts to stimuli that excite his smell, taste, pressure, bodily position, temperature change and hunger. 33 There is no delayed gratification and no concept of time. Therefore the 
repeated, regular and constant recurring rhythm of feeding, making comfortable and changing help to develop his first behavior traits and satisfy this first basic need. Through conditioned reflexes he learns the signs of coming satisfaction, the preparation steps before gratification and then he learns to delay. At the same time he learns to trust in the coming satisfaction. A baby's direct movements include sucking, grasping, and turning the head toward breast and light. He is soon able to focus his eyes and hearing. Random movements lead to definite physical experience as the baby begins to use parts of his body to touch and experience the things he sees. This active exploration of the environment is differentiated and coordinated in response to sensory stimuli. Through grasping and touching the infant develops recognition and perception. He learns that things that can't be touched, only seen, are really there, then, when they can't be touched or seen, are there too. ${ }^{34}$ At first the baby will be content by himself, looking and touching, then he shows a real need for companionship as he responds to the stimulus of voices, laughter and.pleasure and of showing pleasure along with a growing interest in the world.

Next comes a sense of self, of stepping out to explore the world, to test himself and his strength with it and against it, an egocentric kind of life, filled with curiosity and little judgement. 35 Along with his need for physical comfort, touch and things . to touch and companionship develops the need for space as the automitic movements of sitting, crawling, standing and walking are ashieved. He makes comparisons by testing, manipulating and 
sorting and investigates events by imitating them.36 In other words, he learns by playing.

With achieved command of himself and of things, he is ready to move into a broader connection with people, trustworthy adults and increasingly, other children through an imaginative and imitative play life. His behavior is more controlled by cortical reactions to verbal signals than by conditioned reflexes to sensory signals as his speech and thought develop. Generalization and abstraction lead to the formation of concepts, ideas and other thought patterns. Speech develops through imitation and independently of the gradual development of language perception.37

The need for verbal communication is important from the day of birth and is especially important as the child increasingly uses language to express what moves him. Ianguage and the command of speech have a great effect on his behavior as adults use verbal communication to control a child's actions and stimulate or inhibit reactions. Schmidt-Kolmer states that it "serves to confirm, stimulate and instruct, gradually guiding the child's perceptions from sensory-motor learning through trial and error to recognizing by observation and finally to operate with words and thoughts." 38

Not mentioned but an absolute necessity to a child's development is the need for love, warmth, understanding, spontaneous interest, and enthusiasm provided by adults who care about each child as an individual. Lois Murphy states that "children have multiple needs to be met: warm, mothering caretakers provide stimulation, space for activity,..., response to child's efforts, along with lots of fresh air and good food - and a 
chance to experience joy."39

With an awareness of these developmental needs, day care planning can strive to give young children the chance to develop strong, healthy bodies, emotional stability with a positive selfconcept, trusting and independent outlooks, curiosity, and a drive to learn, responsiveness to and considerateness of other people and a capacity for participating in social endeavors and carrying out behavior independently. 40

The Group Day Care Environment: a Balance of Experiences

And now we must find a way to go with the child's capacity to grow and use the environment selectively, complementing and supplementing the child's own individual needs. Prescott and Jones state that "the longer the day for children in group care, the more home as well as nursery school characteristics should be incorporated into the program."4l To provide an atmosphere conducive to healthy development, we can draw on and incorporate the positive aspects of both the home and day care environments (which use the nursery school as its model) and create a balance of experiences to help each child to his frillest and healthiest development within time and space.

In general, the environment contains space, time patterns, things and people - all of which influence the child's sensory, cognitive and motor development which are basic to normal personality and mental development. But, how does the environment work to enhance his growth? According t;o Prescott and Jones it offers him the opportunity to solve real jroblems which include "the need 
to learn:

1. How to cope with one's self - with one's body, with feelings, and with being alone.

2. How to cope with other children.

3. How to cope with adults - their expectations, rules, rewards, and punishments.

4. How to cope with the natural environment dirt, rocks, animals, weather.

5. How to cope with the man-made environment - cars, furniture, toys, written language and so forth." 42

Problem-solving and learning coping mechanisms are important because they enhance a child's sense of self and according to Piaget, "the greater variety of experiences a child copes with, the greater becomes his ability to cope:"43 The home environment does not necessarily run on a smooth schedule which is in many ways an asset for the child. There he learns problem-solving in adult terms at first hand as his mother handles the routine and nonroutine aspects of running a household. He has the opportunity to practice some problem-solving on his own provided he is acting within the limits that his mother will allow. In other words, he has the freedom to choose his activities. Some homes and day care centers are overstimulating and others are limited by space, materials and the rigidity of adults. A balance must be found to meet each child's needs because according to Prescott and Jones, children."gain a keener sense of who they are in relation to the world by making their own cholces. 144

Another experience which increases a child's sense of self includesthe open expression of emotions. Too often day care programs restrict and stifle a child's feelings for fear of "losing 
control". Families on the other hand may overindulge with intense and inconsistent expression of emotion which overwhelms the child and so a balance must also form between the expression and control of emotions.

A healthy balance must also be maintained between the dependence and independence of a child. Some families have difficulty letting go and allowing their children to do things for themselves. On the other hand, day care centers often promote too much independence, sometimes at its extreme called neglect, with the constant turnover of staff who are often too occupied with "program" to be sensitive to a child's need for individual attention. In many cases, it is the "actor-outer" children who receive the individual attention in the form of discipline, while the more quiet children are ignored. Prescott and Jones feel that "a child's strongest impetus toward growth comes from his family's interest in his individual style of development, its encouragement of his new accomplishments, and its readiness to modify its activities and schedules to meet his particular needs." 45

The home also gives the child the opportunity to be alone as his mother goes about her duties. The child thus develops a sense of identity as these experiences give him the chance to make decisions on his own and to decide whether or not to live up to adult expectations for his behavior. Group day care is often too concerned for the safety of the children to allow this type of freedom.

F'amilies and neighborhoods expose the child to a variety of experiences that aide in the socialization process. The child learns 
from his peers, from children of all ages and from adults of both sexes through imitation and role identification. Day care centers often restrict this learning process by grouping the children by age and by insulating them from the daily activities of adults in the home and neighborhood. However, it does provide the child with the opportunity to build relationships with adults and children outside the family, enabling him to grow in confidence and skill in leaving parents and forming relationships.

- Many rural homes offer the experience of exploring the natural environment of trees, earth, rocks, grass, plants, water, animals, weather etc. Day care centers are the result of a manmade world and often neglect to acknowledge man's place in the universe. With asphalt play yards and man-made equipment a child misses the opportunity to discover himself in relationship to the natural environment.

Urban homes are often restricted by space inside and available play areas outside and in this respect day care centers provide for much physical activity. There is usually a variety of equipment to exercise both large and small muscles. However, restrictions to the proper use of the equipment often restrain and stifle a child's imaginative use of it. Prescott and Jones also point out the assets of a more flexible time schedule found in the home in contrast to the more rigid scheduling found in day care centers where coordination of staff hours must be achieved. For the infant and toddler, we must strive to attain a flexible attitude without diluting the need for continuity and routine.

Can such a balance of experiences be achieved when planning 
for agency based group day care for infants and toddlers? I believe it can and the following discussion will describe the proposed guidelines in terms of size, routine aspects, and nonroutine aspects of such a program.

Size of Program

The questionnaire submitted to parents of Fruit and Flower Day Nursery included the following question on size of program: "W1th what size program would you and your child feel most comfortable?" The majority of parents (30 out of 34 responding) agreed that they would prefer a program with from $0-20 \mathrm{chil}-$ dren enrolled, (See Appendix, Table 1). This is interesting because of the implications it suggests. Day care centers are usually the most non-neighborhood form of child care. Usually there is more transportation involved and programs are on an average larger and more impersonal. Also, Ruderman reports that distance from home is associated with dissatisfaction with the arrangement. 46 These results suggest that parents want smaller, more personal programs that are more neighborhood based. Fruit and Flower's satellite program at Trinity Episcopal Church is just such a program with 18 children housed in a church and serving the Northwest neighborhood of Portland. Discussions with the staff of this program indicate that they feel more comfortable with this size in comparison with Fruit and Flower Day Nursery which serves 80 children and where they previously worked before coming to the smaller program. They feel more relaxed, flexible and personal in their style and approach to child care. They are not a part of a huge operation where scheduling is so important. 
They can go outside when and as long as they desire, eat what and when they want. All these points are significant in planning for infants and toddlers who need a more flexible personal and individualized approach.

Agency based infant and toddler group day care programs could be housed in a neighborhood church or even in a.school house or apartment building. In Russia, $5 \%$ of the apartment buildings are reserved for creches (infant care programs). 47 To be connected with a day care program for $2 \frac{1}{2}$ to 6 year olds would be ideal as the mother who needs day care for more than one child of different ages would feel more secure in having her children cared for under the same auspices and in not having to make two separate arrangements. With some form of transportation between the satellite and parent center, this problem would be alleviated.

Use of Space

Preparing our young for the real future and for insuring optimal emotional, intellectual and physical health, depends on providing a child with the chance for individual discovery and problem-solving of everyday real life situations. In order to incorporate these experiences into an infant and toddler program, Schmidt-Kolmer feels that "life should proceed as in a family home so children see and experience how meals are prepared and served, clothes washèd and ironed and mended and kitchen cleaned.

Those that cannot be experienced in reality should be showed through games."48 The rooms of the center should therefore resemble the kitchen with cabinets with pots and pans and utensils to explore, a sink, oven and refrigerator for the preparation of 
meals and the bedroom with beds to make, drawers with clothes to investigate, laundry to fold etc., living room, bathroom, playroom all readily available for real use by adults and explorative and imitative use by the children. If only a large room is available then it can be broken down by room dividers etc., to give the child a feeling of cozy intimate space. Even though two year olds are constantly on the go developing and using their motor skills, they may feel lost in an enormous amount of space. The size and shape and the arrangement of closed and open areas are important and must be considered in relation to the number of children involved, their needs for motor discharge and vigorous activity, their varying interests and needs for areas for quieter types of activities. 49

Other important aspects of the environment include the need for bright colors on walls, bureaus, cribs, tables and chairs etc. to stimilate and generate a feeling of aliveness and happiness. Very young infants ( 3 to 6 months) really enjoy space and need the opportunity to exercise on the floor for muscle development. The floor should be considered as an important level as young children need to roll, tumble, crawl and play with toys on it. Larger movements develop first such as shoulder and kmee before wrist and ankle, hand before finer movements of fingers. There is a sensory delight in movement for its own sake as well as the discovery that space is distance that can be conquered by the body as it runs, falls, climbs, jumps or throws. Schmidt-Kohmer states that a child needs an interplay of stability and continuity in the environment as well as change and variety. 50 stability and continuity 
are provided by the adults who care for him and by a daily routine consisting of sleeping, waking, eating, and care of body needs. Within this framework, a child learns to separate and distinguish the particular from general and changing from constant. It gives him the security he needs to trust his environment and his caregiver's and is a necessary step in helping him reach out and explore. Within this fixed framework, the child is able to respond to a change and variety of impressions and experiences.

Space outside to learn about the natural environment, and to exercise on swings, bicycles, tires, seesaws, climbing and balancing equipment is also important to a child's development. Living in Portland, Oregon requires a covered play area. Walks in the neighborhood are necessary for this age group as they provide fresh air and a constant source of change and variety. Together with the motion of the carriage or stroller and the changing scenery going by, all of a child's șenses are stimulated. Play

Everyday objects and toys in the environment are the means by which a child plays and according to Bladergroen, "play is the manner in which the growing child confronts the world and, through so doing, discovers his own self." 51 Play is the child's living world, a necessity of life and essential for good harmonious adjustment and development. Play takes a functional form in the infant because his mouth is the center of his mental life In feeling and impulse. According to Susan Isaacs, he "eats and thinks with his mouth." 52 . With it the baby acquaints himself with his mother or caregiver, his orm hands, feet and then things. 
His eyes focus on something his hands clutch. Contacts lead him to know and to recognize, to do, to act, to learn. As his mouth, eyes and hands get to know things, practice increases and as he practices, mastery takes place. The growth of being able to do something and thus of knowing how to do something work together as play takes on a more explorative form. According to Bladergroen, the degree of practice determines the forms of exploration, (without exploration there is no stimulus to practice), of possibilities. of expression and of creative play. She states that "in handling things the child's astonishment grows concerning all that exists and is possible; imagination builds up around everything, a new world of its own in which the most remarkable things are possible." 53 Play is social in its direction and in the world of fantasy as it gives the child a chance to practice being mother, father, new baby, policeman, going to bed and getting up. Grown-ups provide him with the models for human roles. Through play he is able to do and to be all the things he may not do, and cannot be in the real world. Fantasy makes it easier for him to fit himself into the real world as it provides "a refuge from the moment-tomoment pressures of real demands, and lets him return to them refreshed." $54^{\circ}$ It is a safety valve for his hidden wishes and fears.

Play also helps a child become conscious of the ego by discovering one's own self as the center of action and exploration. The degree and nature of the ability and knowledge that form the environment for this ego, determine and influence through failure and success the furtber motivation for self-evaluations. Efforts and successes and failures in repeated play experiences 
are as important to a child's mental life as adult activities. Making and destroying also give pleasure as well as relieve nervous tension.

In summary, children's play is seen as the vehicle for development, is vitally linked with healthy development and is even a condition for it. Play is how children amuse themselves; it occupies almost their whole life. Herzka feels that "the history of his play is the history of his personality as it develops and discovers its creative aptitude. Play enables us to perceive the whole child, in his motory, emotional, social or moral life. Iike language, although in another way, play informs us about the child's successive mental structures. It reveals how different the world conceived by the child is from that of adults." 55 Materials

The kind of materials that enhance play consist of everyday objects and toys and the choice of these materials creates the conditions for a child's encounters and thus for his educational and ethical influences in the socialization process. Toys have a functional value in giving the child practice in motor activities. They also have an experiential quality as the child receives sensory impressions and representational value by giving the child the possibility of independent representation. Play materials give a child relationship value as they serve to transmit relationships between the child, and his playmates and with adults. 56 There is also a developmental value in the choice of materials as the child grows and matures. Too often parents shower toys on festive occasions and birthdays instead of according to developmen- 
tal needs. And lastly, materials have an educational value as they enhance a child's capacities for logical understanding, judgement and imagination. All this means that the selection of toys must provide the child with the opportunity to practice manysided functions keeping in mind that a child learns best when the information and materials offered him are in line with subjects in which he has shown a natural interest, involvement and curiosity, when learning is self-motivated and comes from independent pursuit, active involvement and direct experience. 57 One of the problems with the selection of toys in homes is that they are chosen according to what the parents desire. Many parents buy girls girls' toys, and boys boys' toys thereby transmitting a cultural value which tends to set the sexes apart. This can be avoided in the day care setting where boys and girls have the chance to test themselves out with all types of toys.

There are natural toys consisting of water, sand, stones, earth, trees, grass, animals, etc. and everyday objects called cultural toys which should be made available to the child as soon as he can make use of them. These include household objects, consumer goods, and ready-made toys bought from stores. Homemade toys are particularly meaningful as during preparation, a child learns how human capacities can serve to produce and shape something. 58 They represent personal efforts for the child.

There should be occasional toys, such as paper made objects, to enliven a child's daily life which do not need to be taken care of as they are only. Intended 1;0 bring a child quite simple spontaneous foy,. And there should be permanent toys, sturdily 
made and played with and cared for by all.

Infants respond to simple shapes, clearly contrasted colors, well defined sounds and movements especially repetitive movements from rattles, mobiles, music boxes, and mirrors. Objects for touching, feeling, banging, throwing or combining teach the baby the qualities of things and of what he can do with them. As the infant's motor abilities increase, he doesn't need lots of toys as he is using his.own body so much. Such things as a spoon and tray to bang it on, bell, ribbons, box with lid to put things in and take out, wooden bricks give him a sense of power and mastery.

In the second year a child enjoys a ball, a squeaky doll, set of wooden rings and a nest of boxes, a large soft bag to put his treasures in, shoes to try on and books such as Pat the Bunny and: big colorful illustrations to go along with nursery rhymes. It must be remembered that two year olds do not yet understand "taking turns" and need duplicate equipment. Water play in sinks and bathtubs give a child practice in managing a cup, and sand and spoon give him practice at managing food. I suggest that music. from the radio and record player also be a part of everyday experience because it contains the capacity to soothe, excite, charm and lull to sleep.

Outdoor play shows how children seek movement of bodies with toys by running, conquering balance, height, depth and distance. There should be things to help physical growth; climbing frame chairs, and stairs, slide, seesaw, rugs and cushions, and materials for making things: light building blocks, bricks, beads, playdon, paper for tearing, crayoning, painting and glueing, with a balance 
of formal materials for getting to know geometric shapes, sizes and counting. This can be done with sets of blocks graded in size and form,boards and boxes and puzzles for fitting and sorting (Montessori and Creative Playthings are examples), and informal materials like pots and pans, canned foods of varying size and fruits and vegetables. Doing things for himself such as eating, drinking, washing and drying, dressing and putting things away must not be omitted for the sake of time and patience.

According to Morgenstern, "the essence of a toy is that its appeal to the child is direct and not the results of demands or appeals made by some other person. Toys are therefore the most appropriate tools for training infants and children whose language and social skills are still rudimentary". 59 They should be placed so that they are readily available to the child.

$\underline{\text { People }}$

The day care environment conducive to healthy growth for infants and toddlers is made up of space, objects and materials and most important by people as they select and define that space, objects and materials according to the child's needs. They are the main factor in the environment for infants and toddlers who need the security and continuity of repeated daily contacts. They possess stimulus qualities as their time, energy, tempo, understanding, attentiveness, and ease of emotional responsiveness pour into their relationships with the children. Their continuity and consistency contribute to the child's experience of the mother figure and support or interfere with the child's capacity to integrate different experiences. They provide the infant with physical 
care as well as body contact approprate to the child's craving and tolerance.

According to I. B. Murphy, a "caregiver shareswith and evokes pleasurable responses from the infant and recognizes and tries to alleviate unpleasant experiences by providing comfort when a child is hurt. She or he helps the infant and small child with his feelings and gradually the child understands comforting words when accompanied by soothing handling, and in time the words themselves become comforting. " 60 The adult responds to verbal communications, helping the infant connect sounds with objects, actions and specific needs. In summary, he or she responds to what the child initiates, valuing what he offers and building on his spontaneous activity as well as on his communication. ${ }^{61}$ In short, they make the most of each encounter with the child. A reciprocating mechanism is at work as the adult responds to the child who responds to the adults and all this helps to develop a sense of trust, a feeling good about himself, interest in the environment, curiosity, etc. Contact with humans is more important than stimulation from impersonal objects as human relationships are the primary factors in helping a child to learn. These were the conclusions of a study conducted by Harlem Research Center of the City University of N.Y. There were three groups of two year old males: a control group with no extra stimulation, a concept group receiving two hours a week with an adult of concept building stimulation, and a discovery group receiving two hours a week with an adult of discovery learning stimulation. The conclusions stated that learning is not dependent on what the child is taught but on the conditions 
under which he is taught, specifically, the nature of the adultchild relationship. 62

Every activity in a day care center can be an occasion for conversation as the adults share experiences in play, mealtime, body care etc. with the children. Caregivers should feel comfortable singing and repeating nursery rhymes and rolling and tumbling on the floor with the children. This will increase the child's vocabulary and enlarge his capacity for communication in a natural, highly motivated and spontaneous way. A newborn infant learns the value of sound when crying brings attention, cooing brings a smile. As he connects sound with effect, he learns to use it to express definite desires and feelings. Words have no meaning until children have rich contact with things. Susan Isaacs feels that the "most cruel words are don't touch' which means don't learn, don't grow, don't be intelligent." 63 Adults should also be aware of non-verbal communication in children who need to be loved but are unable to express this need. Children develop their own vocabularies at home and so there must be an awareness of these words as well as of individual differences in physiological, social, emotional makeup of each child.

Parents of children attending Fruit and Flower Day Nursery indicated on the questionnaire the qualities they would like to see in the persons caring for their children. Responses included warm, understanding, intelligent, patient, kind, imaginative, individualization of children, "one who loves childhood and does not attempt to adult-ize youngsters," "a person who digs kids and the things they dig." Many parents wrote that they wanted 
the staff to be knowledgeable in early child development. Radin, quoting from a Russian book entitled The Upbringing of Young Children in Children's Establishments, states that adults caring for young children "must not only have the necessary skills and technical know-how, but above all love children, love their work and realize its immense importance." 64

How can such ideal types of people be found? Unlike many academic communities in the world, the United States does not provide for training for infant care workers except for degrees in pediatric nursing and early childhood education. Schmidt-Kohmer describes a three-year training program in Germany for a "nursery nurse" offering both theoretical and practical experience. The theoretical part includes problems of child growth, psychology and education of small children and the practical experience involves child care, dietetics, anatomy, physiology, pathology, prevention and treatment of disease. ${ }^{5}$ Child development programs which will produce more experts in the field are beginning to appear on college campuses.

As earlier stated the staff must provide adult role models of both sexes. Their relationships to the children should be at a minimum of one staff to four children ratio which is recommended by the book, Guidelines for the Care of Infants in Groups wiltten by Sally Provence for the Child Welfare League of America, and by Bettye Caldwell who also suggests that each staff member do something other than child care such as fold diapers etc. 66 In this way, the children experience seeing adult activities such as cleaning, cooking as they follow and imitate their caregivers 
while they are carrying out these duties. It might also cut down on maintenance expenses!

Parents of children attending Fruit and Flower Day Nursery responded to the question, "whom do you think the director of a day care program for infants and toddlers should be?" Appendix, Table 2 describes these responses: 11 preferred an early child development expert, 4 preferred a social worker, 3 preferred a mother, 2 preferred a teacher. Eight had multiple responses and 6 chose other or gave no response. With these results, I would recommend having a qualified pediatric nurse who could take care of emergencies as well as non-emergency situations not requiring a doctor. The questionnaire showed preference for a child development expert of either sex who would be responsible for psychological and child-rearing aspects of the program. A:social worker is also suggested for part of staff to do intakes with the strong recommendation of home visits of newly admitted children to assess the home environment so that it can be coordinated with the center and to keep close association with parents.

Parents benefit from contact with the staff even if it is just for a moment while they deliver and pick up their child. Brief daily reports can be exchanged between parents and the staff who provide a visible model for parents' role as teachers of their children. Since the care of their young children will be provided by two to three major caregivers, the mother will have a constant figure to relate to on a dally basis so that should problems arise, they can be dealt with immediately. There is bound to be some feelings of emotional estrangement between mother and child created 
by the mother's becoming cut off from the child's daily experiences and rivalrous feelings between parent and staff. These can be alleviated if the staff initiates and generates a shared, open and loving feeling towards the parents with whom they share in the socialization process of the child.

Parent Involvement

On the questionnaire parents expressed their desire to be involved in the planning of such a center. Out of 34 responses, 6 preferred group contact, 5 preferred individual, 13 desired both types of contact and 9 did not respond. They saw their involvement on a continuing basis: 15 preferred once a month, 10 as often as necessary, 3 once a week and 7 did not respond, (See Appendix, Table 3).

From the first contact, the staff can reach out to help the parents feel comfortable with their decision to have their children in day care, and prepare their children for separation and day care experience. By involving them from the beginning, parents will feel more eager to make their valuable contributions. For it is the parents' attitude toward day care that is felt by the child. If the parent is not comfortable with it, then the child will not feel comfortable either. Parents can guide the staff in making day care closer to home by bringing favorite objects from home and by introducing some of their unique cultural backgrounds: Parents can also reach other parents. For infants and toddlers, it is especially important for the staff to have regular, short, if possible, daily, contacts with the parents to keep continuity of care for his physical and psychological development and for 
his general health as well as planned formal discussions. Daily records should also keep track of this information.

Grouping of Children

The grouping of infants and toddlers is a debatable issue. The results of the questionnaire (see Appendix, Table 4) indicate that 15 parents preferred their children to be with children of their own age, 5 parents preferred that their children be in mixed groups, 12 wanted a mixture of both and 2 felt that their children should be with the age group they feel most comfortable. These figures are somewhat clouded by the fact that 23 out of 34 parents wanted their infant or toddler in group care; but 22 parents out of 34 would not start their child in a group care program until 2 years (see Appendix, Table 5). The questionnaire did not clarify to the parents responding whether mixture of age groups referred to infants or toddlers, although it was implied; or to their children already attending Fruit and Flower Day Nursery (ages $2 \frac{1}{2}$ to 6 years). The responses might reflect nature of the particular. child and/or parental fears.

There are some strong arguments in favor of mixing infants and toddlers. First of all, children will be grouped roughly according to age in day care and school from age 3 to 18 years. Grouping by age seems to foster competition instead of cooperation and this does not coincide with the values outlined in chepter 1 that will work to build trusting relationships and a better society. Meeting the demands of four 2 year olds would be difficult for one caregiver if separation by age was the policy. Children in this age group are so caught up in the very process of 
playing, doing their own thing. They enjoy the company and exposure of other children, but these don't have to be of the same age group. For the older ones, exposure to younger children can : serve to lessen sibling rivalry when the child's parents have another child.

Older children in the group will see at first hand what is involved in caring for an infant and can begin to help now and then if they want. Early child-rearing techniques will be inculcated by each child as he watches and experiences them in action. Having a mixture of age groups would allow each child to be cared for. -by a minimum of caregivers since that child would not be transferred into older age groups until $2 \frac{1}{2}$ to 3 years when he would move out of the program. This would decrease frequent change in child-staff relationships. Being played with by older children and adults helps the infant become accustomed to different people. Their delight, pride and surprise at a baby's reaction provide an important feedback to the infant and, by enhancing the importance to him of his own achievements, stimulate further efforts on his part. Children learn so much from each other that it would be depriving them of an experience which will have far reaching effects, as boys and girls of different ages learn to spend their leisure time together without constantly. having romantic interest implied.

Schmidt-Kohmer describes some attributes of mixing children of different ages. She found that the younger ones develop faster by imitating older ones. They learn to talk faster and learn to use tie toilet without pressure from adults. Their behavior to- 
wards one another is kinder and more considerate, and older children develop a sense of responsibility and helpfulness as they help to take care of younger children. They require less care themselves and can respond to verbal instruction in activities and behavior. 67 She suggests that the children be divided into "families" as in a regular family. With two caregivers working together with eight children, then individual demands of the children can be met one at a time without causing the child to wait for bathroom, bedroom and meal, because she feels that an infant and toddler program should avoid everything that compels a child to wait about. without doing anything. 68 Each group having a room of their own with separate equipment as well as taking part in daily activities of other rooms - kitchen, laundry etc. will give each child room to grow with the companionship of adults and children. Murphy feels that such continuity of a few basic warm relationships "contributes to the development of a stable core of self, a sense of being valued; a capacity for dependable relationships, a sense of trust and identification with motherly and fatherly adults" 69 and children.

\section{Starting Age}

Another issue receiving a diversity of opinions is the minimum age at which to start a child in the day care experience. As stated earlier, the majority of parents from Fruit and Flower Day Nursery responding to the questionnaire did not feel that a child should begin until after 2 years. Their reasons were that the young child should be cared for in the home. They did not want a school atmosphere which is associated with day care for their 
children and rightly so. It is difficult to envision a "home atmosphere" within a group care center and being able to provide each child with all he needs for a healthy development. But this feeling is a cultural rather than an accurate assessment of the setting and it is the aim of this practicum to clarify and change public attitude toward day care for infants and toddlers. The minimum age at which to begin an infant in group day care depends on the effect that separation from his mother has on the infant's development. Yarrow refers to this as the "critical period concept" and feels that maternal separation is more critical during the development of focused object relationship and after, than for younger children. He also states that social deprivation is more critical during the $3-12$ month period than for the 0 - 3 month period. 70 schmidt-Kohmer supports these theories in her statements regarding adaptation to a new envirorment. She states that environmental change has a slight effect for the 0 3 month old infant but for the $6-24$ month old child it was. difficult to adjust to a new environmental relationship. Change in environment means change in customary relations, a strain on the nervous system and takes the form of fluctuations in physical well-being, disturbance in growth and behavior and increased tendency to illness.71 For the 2 to 3 year old, adjustment is often easier because his nervous system is more flexible and stronger. He has a growing linderstanding of language and increased powers of imagination which makes adjustment easier.

These statements seem to suggest that the minimum age to begin an infant in group day care should $b a$ before he is 3 months old 
and no later than 6 months. At that time the child would be assigned to a group and would stay with that group and the same caregivers until the end of his third year. If a transfer has to be made due to personal preference or difficulty on the part of the caregiver, mother, or child, then it should be made if possible no later than $7-8$ months. Infant day care programs usually transfer a child from the infant to the small children's group at one year which has very unfavorable results. ${ }^{72}$ Facilitating Separation and Adjustment

But, practically speaking, children come into a program at varying ages. Age of child is a factor to consider in facilitating adjustment, but it is how the child is prepared for changes and how he is helped to adjust that is important. To make their adjustments easier, day care must be introduced gradually, one or two hours a day for the first week with the mother present if possible for part of the time so that the child can return to her at any time in order to reassure himself of her availability. ${ }^{73}$ Having a favorite toy or blanket from home often helps a child. In this way the parent and caregiver can get to know each other and discuss the child's needs, health, food, growth, rest and development. The child will feel the mutual understanding and respect between his parent and caregiver and therefore know that he will be in good hands. Discussion of the center's care and values is important before the child becomes full-time as these must be clarified and agreed upon before his entrance. Psychological ard emotional problems arising in the mother because of placing her child in day care, if any, must be worked out as they also 
affect a child's adjustment. If a child is old enough to understand, then he should be told in advance that his parents are having him cared for (not "leaving" him) at the center while they work. Gilbert describes parents as the core of children's lives and "children are concerned about their separation. They want to know and feel that their parents accept the rightness and necessity of care away from them and sense the parents' confidence that the care will be good and that they want it for them. "74 The same. care and preparation should be given when a child or staff member leaves.

Health Care and Discipline

Health care in an infant and toddler day care program is of primary importance because this age group is so susceptible to illness and disease. There must be special attention paid to maintaining cleanliness of the facility, sterilization of the bottles etc. and providing good nutrition and health care. The public health nurse should be responsible for ensuring high standards in this area as well as dealing with such things as poor digestion, colic, diarrhea, constipation, etc. A consulting physician available at all times and perhaps a monthly well-baby clinic operated at the center are strongly suggested. If a child becomes sick and his separation from the group is necessary, then he should be removed from contact with the other children but not necessarily isolated in an isolation room which is often frightening to the child. Schmidt-Kohmer found that respiratory infections were the most common illness and to strengthen a child's resistances, she suggests some hardening processes: daytime naps in the open air, 
sun-baths in the warm weather, rubdowns and good diet. The happy, active, and best developed child is more resistant to disease. 75

Most interractions with young infants occur while bodily needs are met. Caregivers should make the most of these occasions with verbal communication, stimulation and individual attention. If a kitchen is one of the rooms in the day care center then the children can either eat there on a rotating basis or in their rooms as a small group. A relaxed attitude toward food can help to eliminate culturally induced guilt feelings over wasting food and anxiety over eating more for health.

Sleeping for young infants consists of 18 hours a day and should be in a designated sleeping room with cribs, changing table and a caregiver. The infant caregiver is responsible for all the care of the four youngest infants, moving them into their own groups gradually as they spend more and more time awake with the actual transfer being made no later than $6-7$ months. There the infant shall remain until he leaves the program, returning to the nursery for naps until there is no more room in the nursery or until he can nap with his group.

Each caregiver can be called by his first name or nickname which would make it easier for the child to use.

Discipline in a day care center for infants and toddlers often consists of preventing one child from hurting another. Displays of emotion such as anger should be allowed so that the children learn that the loss of emotional control, either by adult or by children, need not be disastrous. Destruction of things that don't matter should be allowed as it helps to release 
nervous tension. Care of objects that do matter is also important for the child to learn. An example of a display of anger in the form of biting should be handled by the adults preventing him from biting by holding him and saying, "I won't let you bite," and reassuring him of love and understanding of his need for power and self-assertion. There should never by any slapping or spanking as these methods only serve to relieve the adults own anger. The toddler is a difficult age group to know, to predict and to plan for as they arouse conflicts which we have ourselves: independence vs. dependence, stubborness vs. angelic submissiveness. 76 
CHAPTER FIVE

\section{JUSTIFICATION AS A SYSTEM}

The justification of these guidelines for infant and toddler group day care can be found in the research already conducted in the field of early child development. The fear of "institutionalism" which Rene Spitz and others have reported finding in foundling hospitals where the impersonal care and understimulation led to deprivation, retardation and even death has affected thinking on group care for infants and toddlers. The children Spitz described suffered from lack of affection, stimulation, challenge, and freedom to act. They experienced congregated and not individualized group care. Day care and institutional care have only one major feature in common: children in groups.

\section{Single versus Multiple Mothering}

The next question to be dealt with is: can agency based group day care for infants and toddlers provide all that is necessary for healthy growth and development without disturbing the infant's ability to form attachments? Absence of matermal attachment is seen as a cause of deviant patterns of affective relationships with other people by Goldfarb, Provence and Lipton and sumaries by Bowlby, Yarrow and Ainsworth. 77 Casler challenges this inference and explains that perhaps deficits shown by non-attached children are more the product of inadequate environmental stimulation than of maternal attachment. 78

Ainsworth describes attachment as an affectional tie to a 
a specific person which may wax and wane as a function of the situation but which as an enduring quality, can survive even adverse socio-economic circumstances. 79 It is characterized by the maintenance of proximity, by mutual pleasure in a relationship and by reciprocal need gratification. In her study of attachment in Uganda 15 month old infants, she found that "warmth of mother, care by people in addition to mother and use of scheduled versus demand feeding bore no relationship to strength of attachment and concluded that, "there is no evidence that care by several people necessarily interferes with the development of healthy attachment. "80 Another project on attachment by Schaffer and Emerson studied longitudinally 60 infants ranging from 21 to 78 weeks. They found indiscriminate attachment behavior during the second quarter and specific attachment during the third quarter of the first year defined as: resistance to separation, calling for mother, positive emotional response shown upon sighting a returning mother, and gaining proximity when she came upon the scene. Their conclusions were that "attachment was unrelated to whether the attachment object had had a major responsibility for the child's physical care; maternal availability to child did not differentiate significantly among infants who formed exclusive attachments from those who attached to more than one object; children who had extensive contacts with other people independent of the nature of the mother-child relationship, tended to show broader attachment patterns than did children who had limited contact with people".81

Are these traits liabilities for children growing up in today's world or are they values and qualities that we need to nurture and foster in our children so that they are prepared to survive in 
in the future. Margaret Mead feels that children in today's world need to go many places without fear and to interact with many people. She questions the advocacy of a very close tie between mother and child, and suggests that wider experiences "in the arms of many individuals in different degress of intimacy, if possible of different races might represent the more adaptive experience for young children. 182

It is the nuclear family which has isolated itself and as a result become so concerned with territoriality, mine and yours. Day care programs actually represent a return toward a pattern that is more normal and adaptive for the species-one of sharing in the socialization process of children. The trend is towards utilizing societies' resources to foster optimal development for its children.

Peer Group Attachment

This is the basic idea behind the Israeli Kibbutz where collective child-rearing takes place. From birth the kibbutz becomes the children's parents by providing good physical care, educating them, socializing them through metapelets (child care givers) and the peer group. Stimulation comes from metapelets and peer group and emotional needs are met mainly by the parents who usually spend a few hours each evening with their children. The parents' feelings of commitment, creativity, and investment are transferred to the community in the kibbutz where everyone knows how much his work contributes to the children's well-being. In this way, pressures from physical care do not interfere with 
emotional giving because according to Bettleheim, "it is the reestablishment of deep emotional family ties that they (the parents) feel would enslave them and their children if they became the infant's main source of security." 83 They want their children to learn that security derives also from the peer group and the metapelet.

According to Bettleheim, security is made up of physical security consisting of food, shelter, rest and other bodily comforts, : a protection from excessive stimulation, and companionship, the filling of social and emotional needs, which can be provided by one mother or the kibbutz. The dynamic counterpart of this same and continuous provider is separation anxiety, the fear of desertion which develops in a child after he has learned to trust and rely on the sameness and continuity of the outside providers. What counts for the infant in the earliest stage of development is the ratio in the infant's experience of basic trust, versus basic mistrust. Bettleheim+states that "the more the child's trust depends on the sameness and continuity of a single provider, the more devastating the basic inistrust caused by the loss of that person. "184 Separation anxiety is reduced for the kibbutz child who, when the outside providers leave or even a cribmate leaves, is not left alone as there are other peers in his room. The kibbutz suggests then, that basic trust can be achieved with much less sameness and continuity of the outside provider so long as continuous providing is guaranteed. Also it suggests that trust in one's self can develop even if there is no threat of the outside provider leaving; that self-control over one's 
asocial urges can develop out of a desire to keep the willing companionship of the peer group. 85

In other studies, Freud and Dann found that children separated from their mothers who have had prolonged contact with each other. show intense peer attachment which can possibly substitute for maternal attachment; and Harlow in his studies: of nonhuman primates, feels that peer attachments are actually more critical for subsequent species' normal social and sexual behavior than is maternal attachment. 86

We have a lot to learn about collective child-rearing and peer group life on the kibbutz and their implications for nurturing healthier and happier people, relationships and a better society. In studies conducted by Israelis, there is strong evidence that the near absence of delinquency is a direct result of kibbutz raised children. There are no battered children in the kibbutz and as Bettleheim states, "in the kibbutz, things can never get as bad as they may between a lone mother and her infant, because there is more than one person taking care of the infant." 87

Maternal and Child Health Intervention and Prevention

In the area of prevention, agency based infant and toddler day care programs will have a great impact as they provide the opportunity for early detection of physical, emotional and social problems in children and their families. Too often, these problems do not come to public attention until the child enters school and in many cases it is too late. According to Caldwell and Richmond, the first three years represent a crucial period for 
for the prevention of learning deficits. 88 By bringing immediate attention to the problem through referral to medical and social services in the community, breakdown in family relationships and health can be avoided. And these preventive health services can be carried into the home and extended to other members of the family. Intervention and prevention services can include unborn children in the form of genetic counseling and prenatal care.

All these services must work to free-up parents from the many stresses and strains of a pressure-producing society so that they can be emotionally free to really give of themselves to their children, and to prepare children to deal with the multiple aspects of the environment and the future.

Keeping versus Developing

Agency based group day care for infants and toddlers offers the child more than just a babysitting service; that is not enough. If offers him the freedom to be himself, to be less affected by his parents: emotional problems if they exist, and the possibility to develop to his fullest capacity physically, emotionally, and intellectually. Agency based group day care provides parents with reliability, quality care, learning opportunities, professional staff and for the person caught in the cycle of poverty, it offers a chance to escape, to be free of the need for public assistance and a hope for their children.

It is my hope that these guidelines represent a concern for the whole child so that as he grows and matures he will experience joy and happiness in learning, feel free to ask questions, to explore, 
to experiment and to be spontaneous. Preparing children to deal with the future, to go with change and to use change and leisure time means to develop his intellect which is the critical, creative, and contemplative side of the mind. According to Senn, intellect "evaluates and looks for the meaning of situations as a whole. It implies a special sense of the ultimate value and the act of comprehension. Socrates struck its essence when he said that the unexamined life is not worth living."89 


\section{CHAPTER SIX}

\section{REMAINING PROBLEMS}

It is my aim that these guidelines will help to overcome public attitude toward group care for infants and toddlers so that it can be recognized as an institutional need and supported on an institutional level. The official position of child welfare organizations is condemnation of any form of group care for children under three except on an experimental basis with some programs emerging on a grass-roots level. Present public attitude toward child care centers in general remains the same pointing to the negative features such as impersonality, excessive structure like school, dangers to health, a facility serving the poor and disadvantaged, untrained personnel, unsanitary conditions, lack of controls, and a dumping ground for parents who do not wat to care for their children. According to Ruderman, these attitudes are the result of applying a "residual framework to an 'institutional' need and they account for lack of availability, public apathy, and absence of support." 90 The service has not yet faced up to the need and therefore it is not providing the appropriate kinds of services. Transportation, cost, no provision for a sick child, serving children from $3-6$ years are a few of the remaining problems. Ruderman feels that the problem's "most basic cause is the absence of a comprehensive philosophy of supplementary child care service, within which day care could be developed as a good and attractive form of supplementary child care, rather than as either a social work service to troubled families, or as a commercialized form of custodial care. Day care at present is 
largely unrelated to the actual total needs for supplementary child care in the community." $" 91$

Guidelines for infant and toddler group care programs are part of the answer but multiple problems need multiple approaches which according to Emlen "seek to understand the varied needs of the day care consumer and that pursue child development objectives within a context of programs designated to strengthen the contributions of supplemental child care to family life." 92

- Families in the United States have relinquished part of the socialization process of their children to institutions. Urie Bronfenbrenner raises the cultural question of whether day care separates the child from his family and reduces families' feelings of responsibility or whether it helps families maintain their role as the primary and proper agent for the process of making human beings human. 93 He feels that in a society where goals are clear day care is possibly good. But the United States has no clear cut goals. When day care can occupy two full years of the first seven years $(8,000$ hours) of waking hours, a center cannot help but teach social values and beliefs.

Day care can serve to enhance family life but our goals are not clear cut. The parent-surrogate institutions which have taken over part of the socialization process do not demand the same emotional comitment that the kibbutz demands of its members. Urie Bronfenbrenner feels that "one of the signs that a society is beginning to lose its vitality is that children cease to be central in the lives of the people. If you want to turn society around, it's around children that you have the hope of doing it." 9 't 
I believe our Israeli Kibbutz is our children. Whether they are raised at home, in family day care or group day care, it is our responsibility that they receive the best care. Now, that care can be provided by group day care, in the future, we must regard child-rearing as not something for everyone, but, only for those who really want to and are trained to raise children. For, as Isaacs states "Children need all our affection and sympathy: but they need also all our intelligence and our patient and serious efforts to understand the ways of their mental growth."95 
QUESTIONNAIRE

for parents of children using Fruit and Flower Day Nursery

H1! I am a student at Portland State University School of Social Work and am interested in your feelings about group day care for infants and toddlers (up to $3 \mathrm{yrs.}$.). Your opinions would be most helpful to me in preparing a research paper on day care. Would you please fill in this questionnaire and return it to the office at your early convenience.

Thank you for your help.

Sincerely,

Elizabeth $\mathrm{H}$. Minifie

Please list your children by first name, age and sex.

Name

Name

Name .

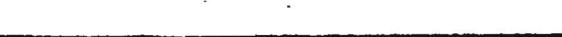

Marital Status: Married

Divorced

Separated

Single

Widow, widower

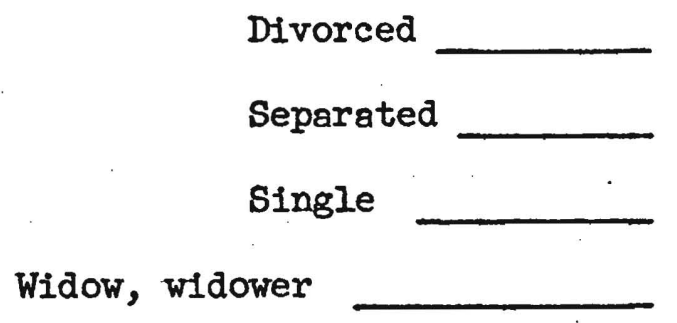

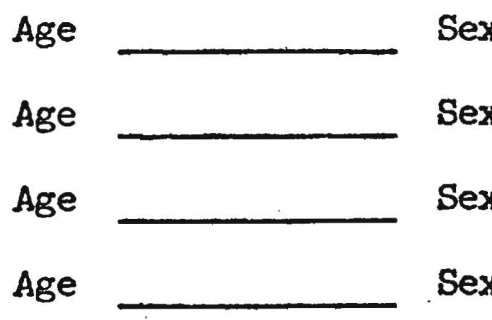

Sex: Male

Are you working at home , in job training , other ? , in school

If applies: Your spouse is working school , at home other ? , in

How is/was your infant or toddler (0-3 yr.) cared for? relative neighbor day care home , was it licensed? group day care in home care

Would you want your infant or toddler in group day care? Yes ___ No Why?

With what size program would you and your child feel most comfortable?

$0-20$ children 40-60 childrer 20 to 40 children 60 and over

How young would you start your child months. 
Page 2

Questionnaire

How many hours of the day do/did you need care for your infant or toddler? Monday Tuesday hours

Wednesday hours

Thursday hours

Friday

hours

Whom do you think the director of a day care program for infants and toddlers should be?

Teacher

Nurse

Mother

Social Worker
Early Child Development Expert Other

Sex: Male

What qualities would you like to see in the persons caring for your children?

Would you want your child to be grouped with:

Children of his own age

Mixed age group 0-3 yrs.

Both

Since planning for day care can only be done by involving the parents it serves, how do you best see your involvement on a continuing basis?

Are you willing to meet with the staff?

Individually

In a group

In your home

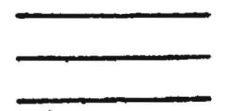

Comments :
Once a week

Once a month

Other 
TABJE 1

Size of day care program preferred for infants and toddlers by families with children enrolled in Fruit and Flower Day Nursery:
0 - 20 Children
30 Families
$20-40$ Children
2 Families
$40-60$ Children
o Families
60 and over
0 Families

No preference

2 Families

Total:

34 Families responding to questionnaire 
TABLE 2

Preferences for director of infant and toddler day care program:

MULTTPLE RESPONSES

SINGLE RESPONSES

10

Teacher

2

2

Nurse

7

Mother

3

8

Social Worker

4

Early Child Development

19

Expert

11

3

Other

3

3

No Opinion

3 
TABLE 3

Type of contact with staff preferred by parents responding to questionnaire:

$\begin{array}{lc}\text { Group: } & 6 \\ \text { Individual: } & 5 \\ \begin{array}{l}\text { Multiple (2 or more } \\ \text { categories checked): }\end{array} & 13 \\ \text { No Response: } & 10 \\ \text { Total: } & 34\end{array}$

Frequency of contact with agency:

Once a week:

4

Once a month:

15

Other:

8

No Respónse:

7

Total:

34 


\section{TABLE 4}

Grouping of children preferred by parents responding to questionnaire:

Own Age:

Mixed:

Both:

According to Child's

Comfortableness:

Total: 


\section{TABLE 5}

Response to whether parents wanted their infant or toddler in group day care.

Yes:

23

No:

8

No Response:

3

Total:

34

Response to how young they would start their child.

Under 1 year:

Under 2 years:

Over 2 years

Total: 
1 Howard S. Becker, ed., Social Problems (John Wiley \& Sons, Inc., New York: 1966), p. 2

2. Florence A. Ruderman, Child Care and Working liothers (Child Welfare League of America, Inc., New York: 1968), p. 348

3 Ibid., p. 339

4 William V. Shannon, "A Radical, Direct, Simple, Utopian Alternative to Day Care Center," New York Times Magazine (The New York Times Company, New York: 1972), p. 71

5 Elizabeth Herzog, Children of Working Mothers (U.S. Department of Health, Education and Welfare, Social Security Administration, Children's Bureau Washington, D.C.: 1960), p. 19

6 Howard M. Halpern, "Alienation from Parenthood in the Kibbutz and America," Marriage and Family Living, February, 1962, Vol. 24 , No. 1, p. 44

7 Phillip Fellin, "A Reappraisal of Changes in American Family Patterns" Social Casework, May, 1964, Vol. 45, p. 266.

8 E. Belle Evens, Beth Shub and Marlene Weinstein, Day Care (Beacon Press, New York: 1971), p. XI

9 Ruderman, op. cit., p. 338

10 Ibid., p. 304

11 Helen E. Rees, Deprivation and Compensatory Education (Houghton Mifflin Company, Boston: 1968), p. 19

12 Edmund Gordon and Doxey Wilkerson, Compensatory Education for the Disadvantaged (College Entrace Examination Board, New York: 1966), p. 188

13 Ruderman, op. cit., p. III

14 From notes taken from a speech by Margaret Mead at a conference on Adolescence and its Problems March 3, 1972, in Portland, Oregon.

15 Ruderman, op. cit., p. 211

16 Ruderman, op. cit., p. 298

17 Milton Wilner, "Unsupervised Family Day Care in New York City", Child Welfare, June 1969, Vol. 48, No. 6, p. 343

18 From results of Questionnaire submitted to Fruit and Flower Day Nursery parents. 
19 Arthur C. Emlen, "Realistic Planning for the Day Care Consumer", reprinted from The Social Welfare Forum, 1970, published for the National Conference on Social Welfare, Columbus, Ohio, p. 13

20 Ruderman, op. cit., p. 350

21 Ibid., p. 331

22 Ibid., p. 310

23 Ibid., p. 335

24 Lois Barclay Murphy, "Issues in Research", Children, March, 1969, Vol. 16, No. 2, p. 47

25 Bettye M. CaIdwell, "The Rationale for Early Intervention," Exceptional Children, October, 1970, Vol. 36, No. 10, p. 719

26 Sally Provence, "A Three- Pronged Project", Children, March, 1969, Vol. 16, No. 2, p. 53

27 Susan Coles, "Search for the Truth about Day Care", New York Times Magazine, (The New York Times Company, New York: December 12, 1971), p. 84

28 Ruderman, op, cit., p. 356

29 Ibid., p. 358

30 Dorothea Gilbert, "Education and Growth Needs of Children in Day Care", Child Welfare, January, 1970, p. 15 .

31 Ibid., quoted from U.S. Children's Bureau Publication No. 337, (U.S. Department of Health, Education and Welfare, Washington, D.C.: 1952, republished 1965), p. .4

32 Eva Schmidt-Kohmer, "Organization of Livịng and Educational Conditions for Infants and Small Children in Children's Institutions", Care of Children in Day Centres, (World Health Organization, Geneva, Switzerland: 1964), p. 33

33 Ibid., p. 33

34 Susan Isaacs, The Nursery Years, (The Vanguard Press, New York: 1936), p. 18 .

35 Gilbert, op. cit., p. 16

36 schmidt-Kohmer, op, cit., p. 33

37 Ibid.; p. 34 
38 Ibid., p. 35

39 Iois Barclay Murphy, "Issues in Research", Children, March, 1969, Vol. 16, No. 2, p. 48

40 Ibid., p. 50

4.1 Elizabeth Prescott and Elizabeth Jones, "Day Care for Children, Assets and Liabilities", Pacific Oaks Notes (Pacific Oaks College, Pasadena, Califormia, Fall, 1971) (reprinted from Children, March/April 1971, Vol. 18, No. 2), p. 20

42 Ibid., p. 23

43. Milton J.E. Senn, "Early Childhood Education For. What Goals?", Children, January', 1969, Vol. 16, No. 2, p. 9

44 Prescott and Jones, op. cit., p. 28

45 Ibid., p. 25

46 Ruderman, op. cit., p. 285

47 Norman Radin, "Preschool Programs of the U.S.S.R.", Child Welfare, January, 1970, Vol. 49, No. 1, p. 31

48 Schmidt-Kohmer, op. cit., p. 51

49 Lois B. Murphy, "Individualization of Child Care and its Relation to Environment", Laura L. Dittman, ed., Early Child Care: the New Perspectives, (New York: Atherton Press, 1968), p. 72

50 Schmidt-Kohmer, op. cit., p. 36

51 Wilhelmina J. Bladergroen, "The significance of Play for the Development of the Child", International Child Welfare Review, .. August, 1969, p. 24

52 Isaacs, op. cit., p. 24

53 Bladergroen, op. cit., p. 24

54 Isaacs, op. cit., p. 11

55 Heinz St. Herzka, "The Significance of Toys in the Child's Maturation", International Child Welfare Review, August, 1969, p. 2

56 Ibid., p. 5

57 Sylvia Krown, "Preschool Programs for Disadvantaged Children", Children, Vol. 15, No. 6; pp. 237-238 
Herzka, op. cit., p. 4

59 F. S. Morgensterm, "Toys for Handicapped Children", International Child Welfare Review, August, 1969, p. 10

60

L. B. Murphy, Iaura L. Dittman ed., op. cit., p. 74

61 Ibid., p. 73

62 Francis H. Palmer, "Leaming at Two", Children, Vol. 16, No. $2, \mathrm{p} .56$

63 Isaacs, op. cit., p. 72

64 Norman Radin "Preschool Programs in the U.S.S.R.", Child Welfare, January, 1970, Vol. 49, No. 1, p. 33

65 Schmidt-Kohmer, op. cit., p. 41

66 Bettye Calỏwe11, p. 34

67 Schmidt-Kohmer, op. cit., p. 49

68 Ibid., p. 40

69 Lois Barclay Murphy, "Issues in Research", Children, Mareh, 1969, Vol. 16, No. 2, p. 49

70 L. J. Yarrow, "Measurement and Specification of the Early Infant Environment", Care of Children in Day Centrës, (World Health Organization Geneva: 1964), p. 143

71 schmidt-Kohmer, op, cit., p. 42

72 Ibid., p. 43

73. Peter B. Neubaurer, "The Third Year of Life: the Two Year 01d", Laura I. Dittman, ed., op. cit., p. 64

74 Gilbert, op. cit., p. 18

75 Schmidt-Kohmer, op. cit., p. 43

76 Sally Provence, from notes taken at Child Welfare League Conference, Portland, Oregon, May 4 and 5, 1971

77 B. M. Caldwell and others, "Infant Day Care and Attachments", Ameiican Journal of Orthopsychiatry, April, 1970, Vol. 40, p. $399^{\circ}$

78 Ibid., p. 399

79 Ibili., p. 399 
80 M. Ainsworth quoted by Caldwell and others, Ibid., p. 400

81

Caldwell. and others, op. cit., pp. 398-399

82 Margaret Mead, quoted by Caldwell and others, op cit., p. 399

83 Brtmo Bettleheim, The Children of the Dream, (Avon Books, New York: 1969), p. 110

84 Ibid., p. 83

85 Ibid., p. 82

86 Caldwell and others, op. cit., p. 399

87 Bettleheim, op, cit., p. 137

88 B. M. Caldwell and J. B. Richmond, "Programmed Day Care for the Very Young, a preliminary Report", Child Welfare, Vol. 44, No. 3, March, 1965, Vol. 44, No. 3, p. 138

89 Senn, op, cit., p. 12

90 Ruderman, op. cit., p. 314

91 Ibid., p. 96

92 Arthur c. Emlen, op. cit., p. 142

93 Susan Coles, op. cit.; p. 94

94 Urie Bronfenbrenner, quoted by Ruth Galvin, "Somebody - Let it, Please God, Be Somebody", Time Magazine, December 28, 1970, p. 37

95 Isaacs, op, cit., p. 2 and 3 


\author{
Erikson, Erik H., \\ Fraiberg, Selma H., \\ Goodman, Mary Ellen, \\ Neill, A. S., \\ Pines, Maya, \\ Rabin, Albert I., \\ Spiro, Melford E.,
}

Childhood and Society, W.W. Norton and Company, Inc., New York, 1960.

The Magic Years, Charles Schribner's Sons, New York, 1959.

The Culture of Childhoed, Teacher's College Press, Columbia University, New York, 1970.

Summerhill, Hart Publishing Co., New York, 1960.

Revolution in Learning, Harper and Row Publishers, New York, 1966.

Growing Up in the Kibbutz, Springer Publishing Company, New York, 1965.

Children of the Kibbutz, Schocken Books, New York, 1965.

Spotlight on Day Care, proceedings of the National Conference on Day Care Services May 13-15, 1965, U.S. Department of Health, Education, and Welfare, Welfare Administration, Children's Bureau, Washington, D.C., 1965.

On Rearing Infants and Young Children in Institutions, Witmer, Helen L., ed., Chilldren's Bureau Research Reports, U.S. Department of Health, Education, and Welfare, Social and Rehabilitation Service, Children's Bureau, Washington, D.C., 1967 